\title{
山岳系国立公園利用者の感動，満足，ロイヤルティ，心理的効用の関係性 \\ Relationship among Mountaion National Parks visitors' impressions, satisfaction, loyalty and psychological benefit
}

\author{
五木田 玲子* 愛甲 哲也**
}

\section{Reiko GOKITA Tetsuya AIKO}

\begin{abstract}
The principal role of National Parks are providing unusual scenery and recreation opportunity and conserving biodiversity. Promoting utilization of them also contributes to visitors' health and culture of our society. Visiting parks might make a lasting impression on visitors, and then satisfied visitors could affirm loyalty to parks and get psychological benefits. There have been less investigations regarding with the psychological benefits of National Parks in Japan. Thus, we conducted a questionnaire surveys at four popular Mountaion National Parks in Japan, Shiretoko, Nikko, Kamikochi, and Tateyama, to identify the relationship among visitors' impressions, satisfaction, loyalty and benefit. As a result, "nature appreciation," "enriching the mind," and "environmental awareness and understanding" are considered as great benefits due to visiting parks. Types of benefits are different by activities visitors attended. We also found the significant relationship between impression and satisfaction or benefit. The benefit has larger influence on their willingness to revisit and recommendations to others than satisfaction. Promoting National Parks utilization should pay attention to offering impressive experience in parks and the effect on visitors' loyalty.
\end{abstract}

Keywords: psychological benefits, visitor, national park, satisfaction, impression, loyalty キーワード：心理的効用, 利用者, 国立公園, 満足, 感動, ロイヤルティ

\section{1. はじめに}

国立公園をはじめとする自然公園には，我が国を代表する観光 資源が多く含まれており，たくさんの利用者が訪れている。そし て，美しく繊細で，または雄大で圧倒される景観に触れたとき， 人は心から感動する。こういった観光活動を通して感性は磨かれ, 心の中に蓄積されることから，観光は「真の豊かさ」を測るもの さしとも言われている 1)。しかし，近年，観光は地域社会への経 済的な効果に注目が集まることが多い。そこで，観光のもつ根源 的な力を改めて見つめ直し，利用者の観点から，国立公園利用が もたらす感動や効用といった心理的な効果について改めて考える。

日本における国立公園の利用者意識に関する研究は，環境だけ でなく公園利用者の来訪動機などの心理的側面が満足感に影響を 与えることを明らかにした小林らによる研究 ${ }^{2)}$, 登山者数の許容 限界が満足に与える影響を分析した混䧱感評価と収容力に関する 愛甲らによる研究 3)，アメニティとディスアメニティの概念を用 いた満足の意識構造から問題の重要度を把握した山本らによる研 究 4)などが挙げられるが，利用者の心理的効用という観点から調 査されているものは少ない。野外レクリエーションの効用に関す る調査研究は, 欧米を中心に進められてきた5) 6)。アメリカのレク リエーション研究においては, 野外レクリエーションにおける効 用は，「レクリエーション活動後における好ましい変化」と定義さ れており 6)，アウトドアレクリエーションから得られる具体的な 効用が列挙されている7)。

一方で，感動については，欧米ではそもそも感動に相当する単 語表現がほとんど見当たらないことから，研究がされてこなかっ た8)。日本においては, 感動は,「深く物に感じて心を動かすこと」 と定義され 8), 心理学の分野で研究が進められており, 感動体験 は個人の何かを変化させる契機となるだけでなく，その変化を持 続させる原動力となること 9)が明らかとなっている。但し，自然 公園を対象としたものとしては，感動した自然風景の視点場と視 対象を分析した研究 ${ }^{10)}$ はあるものの, 感動が及ぼす影響や満足と
の関係性については深く検討されてはいない。

感動や効用と関連する概念として満足やロイヤルティがある。 ロイヤルティは，サービス産業分野において「環境変化に関わら ず，将来にわたって特定のブランドやサービスを使い続けたいと いう強い想いと定義されており 11), 観光分野では, 行動的ロイ ヤルティを「再来訪意向」, 態度的ロイヤルティを「紹介意向」と して扱っている 12)。満足は, 「感情の総合勘定」13) と定義されて おり, 属性, 期待, 認知されたサービス品質, 認知されたサービ ス価值が影響しており，さらに満足を向上寸ることでロイヤルテ イも高まるという因果関係が確認されている（図一1上）14）図 -1下は，筆者が各用語の定義 6) 8) 11) 13)に従い，時間軸にもとづい て感動，満足，効用を配置したものであるが，感動や効用が，満 足・ロイヤルティの意識構造においてどのような位置付けにある のかは明らかとなっていない。なお，このような項目間の関係性 を分析する手法としてパス解析があるが，最初からデー夕を適切 に反映したモデルを構築することは難しく，多くの場合，修正指
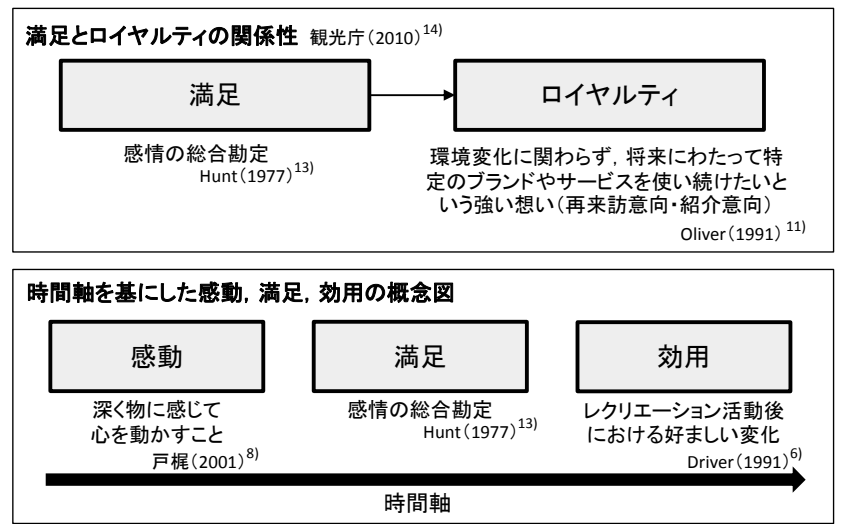

図-1＼cjkstart満足とロイヤルティの関係性及び 感動, 満足, 効用の概念図

\footnotetext{
*公益財団法人日本交通公社 **北海道大学大学院
} 
標などを利用してモデル探索を行うことが必要とされている 15)。

そこで，本研究は，国立公園がもたらす感動や効用といった心 理的な効果に着目し，それら効果の向上及び国立公園利用の促進 に資するため，日本の国立公園を利用することによって得られる 効用の特徵を明らかにするとともに, 効用・感動・満足・ロイヤ ルティの関係性を明らかにすることを目的とした。なお，日本の 国立公園は，山岳や海岸，海中，湿原景観などを含む多様な構成 となっているが，資源性によって得られる結果が異なることも考 えられることから, 本研究では, 古くから指定され, かつ, 最も 多いタイプである山岳系国立公園に対象を絞っている。具体的に は，以下の 3 点を論点とした。

・山岳系国立公園を利用して得られる心理的効用の特徵は何か。

・どのような活動を行うかによって得られる効用は異なるのか。

・感動や効用は, 満足やロイヤルティとどのような関係にあるの か。行う活動によって，その関係性は変わるのか。

なお，本研究を進めるにあたり，有識者で構成される「自然公 園の利用者意識に関する研究会」16)を設置し, 助言を得ながら研 究を進めた。

\section{2. 調査概要}

\section{（1）効用の設定}

アウトドアレクリエーションから得られる効用は，個人におけ る効用，社会的文化的効用，経済的効用，環境への効用の 4 つに 分類され，さらに，個人における効用は，心理・精神的効用，健 康面における効用の 2 つ分けて整理されている7）(表一 1 左）。
本研究の対象は心理的効用であるため, 研究会では主にこの分類 内の効用に着目し, 列挙された効用の中から, どの効用を本研究 で取り上げるべきか検討を行うこととした。検討の前提としては, 国立公園利用が人々にもたらす様々な効用を包含する総合的な指 標（総合効用）を「人生の豊かさへの貢献」と設定した。そして, 列挙されている効用の中から, 人生の豊かさを感じる上でより積 極的に貢献すると考えられる「自己感謝・満足」を中心に，対象 とする効用の抽出を行った。まず初めに, 複数の分類に重複して 挙げられている「美に対するより深い理解」,「創造力醸成」,「情 緒と感情のポジティブな変化」,「環境への配慮」を, 次に, 自然 に関する内容が含まれている「自然に対する理解力」, 「自然と個 との一体感」を, さらに, 人生の豊かさと親和性が高いと考えら れる「自己実現感・充実感, 「冒険心」, 「自信」, 「友情・恋愛・ 家族感情の醸成」を取り上げることとした。

\section{（2）調査方法}

本研究では, 公園利用者に対して, 自己記入方式によるアンケ 一ト調查を実施した。調查対象地は, 様々な年代の利用者が想定 されること, 日帰り・宿泊双方の利用があること, 自然観賞だけ ではなく, 登山や八イキング, 温泉など現地で行う活動が多様で あること, 山岳地域を対象としつつも, 対象エリア内の資源構成 が, 滝, 湖, 川, 湿原など多様であること, 利用者が調査対象地 を一体のエリアとして捉えることができることといった観点から， 知床国立公園知床地域, 日光国立公園奥日光地域, 中部山岳国立 公園上高地地域, 中部山岳国立公園立山地域の 4 地域を選定した。 調查場所は, 多様な利用者の意見を得るため, 多くの利用者が通

表-1 本研究で対象とする効用の整理

\begin{tabular}{|c|c|c|c|c|}
\hline \multicolumn{4}{|c|}{ アウトドアレクリエーションから得られる効用 } & 個別効用の質問項目 \\
\hline \multirow[t]{10}{*}{ I.個人における効用 } & \multirow[t]{9}{*}{ 1. 心理·精神的効用 } & 1)精神衛生上の効用 & 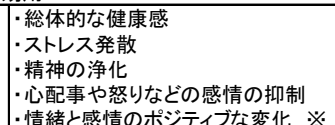 & \\
\hline & & 2)個人の発達·成長における効用 & 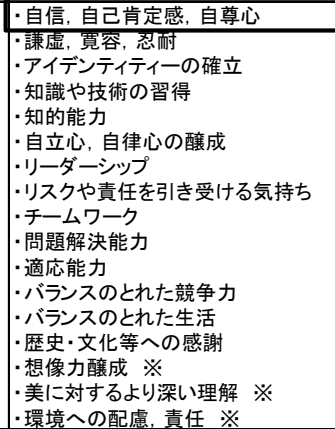 & ・自信が湧いてくる \\
\hline & & 3)自己感謝·満足 & $\begin{array}{l}\cdot \text { 解放感 } \\
\text { ·高揚感, 興奮 } \\
\text { •ノスタルジアア } \\
\text { ·高い精神性 } \\
\text { ·超越体験 }\end{array}$ & \\
\hline & & & $\begin{array}{l}\cdot \text { 自己実現感 } \\
. \text { 充䒠感 }\end{array}$ & ·生活に充実感を感じるようになる \\
\hline & & & $\begin{array}{l}\text { ·冒険心, チャレンジ精神 } \\
\text { ·自然に対する理解力 } \\
\text { ·自然個との一体感 }\end{array}$ & $\begin{array}{l}\cdot \text { チャレンジ精神が涌いてくる } \\
\text { ·自然が好きになる } \\
\text { ·自然が身近になる }\end{array}$ \\
\hline & & & ·美に対するより深い理解 ※ & ·美しいものを見ることが好きになる \\
\hline & & & ·想像力醸成 ※ & ·想像カが豊かになる \\
\hline & & & - 情緒と感情のポジティブな変化 ※ & $\begin{array}{l}\text { ·考え方や気持ちが前向きになる } \\
\text { ・明日からまた頑張ろうと思うようになる }\end{array}$ \\
\hline & & & ·環境への配慮, 責任 ※ & ·自然環境を大切にするようになる \\
\hline & \multicolumn{2}{|l|}{ 2. 健康面における効用 } & $\begin{array}{l}\text { ·アンチエイジング } \\
\text {-禁煙 } \\
\text { ·熟睡 など }\end{array}$ & \\
\hline \multicolumn{3}{|l|}{ II. 社会的文化的効用 } & ·友情·恋愛·家族感情の醸成 & ・家族や友人を大切にするようになる \\
\hline & & & $\begin{array}{l}\text { ・ミュニティーの誇り } \\
\text { ·都市・農山渔村交流 など }\end{array}$ & \\
\hline \multicolumn{3}{|l|}{ III. 経済的効用 } & - 医療費の節減 & \\
\hline & & & ·生産性の向上 & \\
\hline \multirow{2}{*}{\multicolumn{3}{|c|}{ IV. 環境への効用 }} & ·地域経済波及効果 など & \\
\hline & & & $\begin{array}{l}\text { ·都市緑化による大気浄化 } \\
\text { ·施設維持 } \\
\text { ·生物多様性保全 など }\end{array}$ & \\
\hline
\end{tabular}


過若しくは滞留する地点を調査地点として選定し，それぞれ，知 床五湖高架木道出入り口，華厳の滝駐車場・赤沼駐車場（戦場ヶ 原散策路入り口）・三本松駐車場（戦場ヶ原展望台），上高地バス ターミナル, 室堂ターミナルとした。調査対象者は外国人を除く 大学生以上の男女全員で, その場所での滞在を終えて州る人とし た。調査方法は，調査員が利用者に返信用封筒付き調査票（後納 郵便）を手渡し配布し，自宅に戻った後，記入してポストに投函 するよう依頼した。調査票の内容は個々人の意識に関するものが 中心のため, 同行者にかかわらず対象者全員に配布した。また, 1 時間あたりの配布上限枚数を設定し, 時間帯に偏りがないよう 考慮した。なお，上高地では，宿泊施設における留め置き調査も 並行して実施した。調査は 2011 年 7〜8 月 (夏期調査), 9 10 月 (秋期調査) の 2 期実施した。 4 地域とも，利用のピークが夏 休夕期間と秋の紅葉期間の 2 期存在することから，両期間を調査 時期に設定した。知床は他に複数の調査が予定されていたため, 利用者の混乱を招かぬよう他調査実施日との重複を避け，配布枚 数を減らし，夏秋期ともに 3 日間の配布期間とした。日光，上高 地，立山については，夏期は夏休み期間に 8〜9 日間，秋期は紅 葉時期にあわせて 5〜7 日間，調査票の配布を行った。回収期限 は，各地点とも調査票配布後 1 ケ月間とした。その結果，配布総 数 18,800 件に対し, 有効回答数は 6,006 件，回収率は $31.9 \%$ で あった (表一2)。

調查項目は，総合効用，感動，満足について，それぞれ「今回 の旅行は自分の人生を豊かにすると思いますか (総合効用)」,「今 回の滞在で感動はありましたか (感動)」,「今回の滞在の満足度を お答えください(満足)」と尋ねた。ロイヤルティについては，「家

表一2 調査票の配布 · 回収

\begin{tabular}{|c|c|c|c|c|c|c|}
\hline & & 全体 & 知床 & 日光 & 上高地 & 立山 \\
\hline \multirow{2}{*}{ 調査日 } & 夏期 & & $8 / 9 \sim 11$ & $\begin{array}{c}8 / 5 \sim 9 \\
8 / 21 \sim 24\end{array}$ & $7 / 29 \sim 8 / 6$ & $\begin{array}{c}8 / 4 \sim 8 \\
8 / 21 \sim 23\end{array}$ \\
\hline & 秋期 & & $9 / 23 \sim 25$ & $\begin{array}{l}10 / 11 \sim 15 \\
10 / 24 \sim 28\end{array}$ & $10 / 10 \sim 16$ & $\begin{array}{c}9 / 26 \sim 28 \\
10 / 11 \sim 12\end{array}$ \\
\hline \multirow{3}{*}{ 配布数 } & 夏期 & 10,400 & 900 & 5,000 & 2,500 & 2,000 \\
\hline & 秋期 & 8,400 & 900 & 3,000 & 2,500 & 2,000 \\
\hline & 計 & 18,800 & 1,800 & 8,000 & 5,000 & 4,000 \\
\hline \multirow{3}{*}{ 回収数 } & 夏期 & 3,078 & 185 & 1,339 & 850 & 704 \\
\hline & 秋期 & 2,928 & 229 & 886 & 992 & 821 \\
\hline & 計 & 6,006 & 414 & 2,225 & 1,842 & 1,525 \\
\hline \multicolumn{2}{|c|}{ 回収率 } & $31.9 \%$ & $23.0 \%$ & $27.8 \%$ & $36.8 \%$ & $38.1 \%$ \\
\hline
\end{tabular}

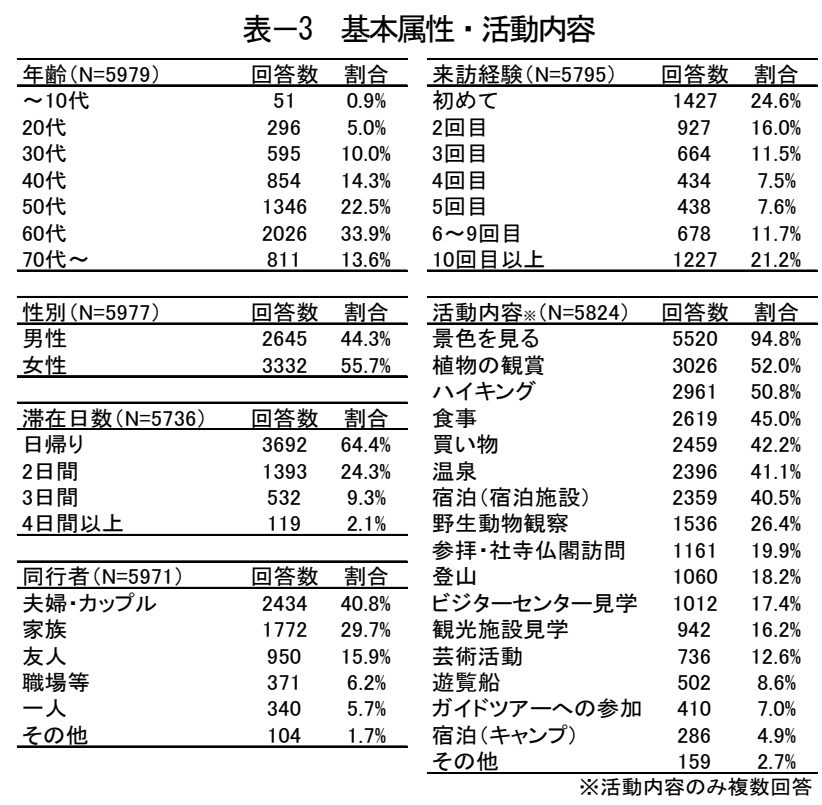

族や親しい知人に当該地域を紹介したいですか（家族や親しい知 人への紹介意向)」,「 1 年以内に, 当該地域に来訪したいですか (当 該地域への 1 年以内の再来訪意向)」,「別の季節に，当該地域に 来訪したいですか（当該地域への別の季節の再来訪意向）」,「1 年 以内に，自然豊かな観光地に来訪したいですか（自然観光地への 1 年以内の来訪意向)」の 4 項目について把握した。なお, 再来訪 の 1 年以内という設定は, 観光庁が実施している各種調査 14) 17) を参考とした。個別効用については, 表一1右の 12 項目について

「今回，本地域を訪れたことによって，ご自身にどのような変化 があると思いますか」と尋ねた。総合効用, 感動, 満足, 4 項目 のロイヤルティ，個別効用のいずれの項目においても， 7 段階の リッカート尺度（1＝全くそう思わない・全く感動しなかった・ 大変不満, $7=$ 大変そう思う ・大変感動した・大変満足）を設定 した。併せて, 年齢, 性別, 滞在日数, 同行者, 来訪経験, 現地 での活動など基本的な属性や旅行内容について取得した。得られ たサンプルの概要は，表-3の通りであった。

分析方法については, 山岳系国立公園利用で得られる効用の特 徵を把握した後に，それらの効用が活動内容によって左右される のかを明らかにするため，活動の有無による効用の大きさについ て 検定を行った。次に，効用が満足や感動とどのような関係に あるのかを明らかにするため, 図一 1 で整理した概念図に基づい て基本モデル構築し, パス解析を行った。さらに, 効用・満足 · 感動の関係性が公園間や活動間によって異なるかについても分析 を行った。統計解析は, IBM SPSS Statistics22 を用いて行った。 なお，パス解析に当たっては，R（3.1.1）及び lavaan パッケー ジ（0.5-16）を利用した。

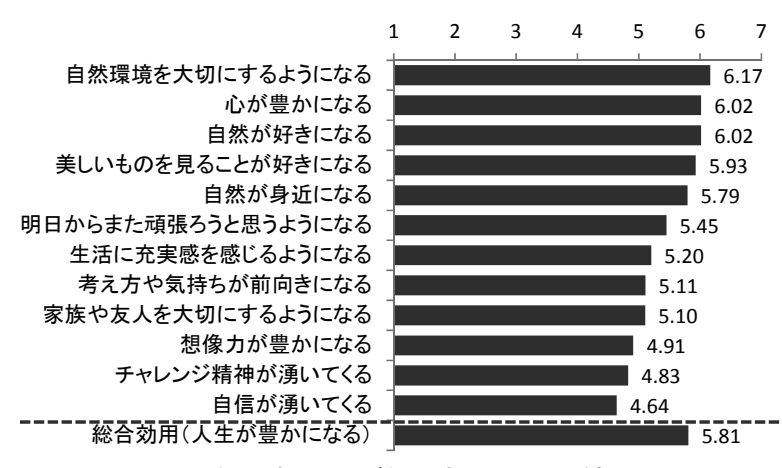

図-2 個別効用及び総合効用の平均值

表-4 個別効用の因子分析結果

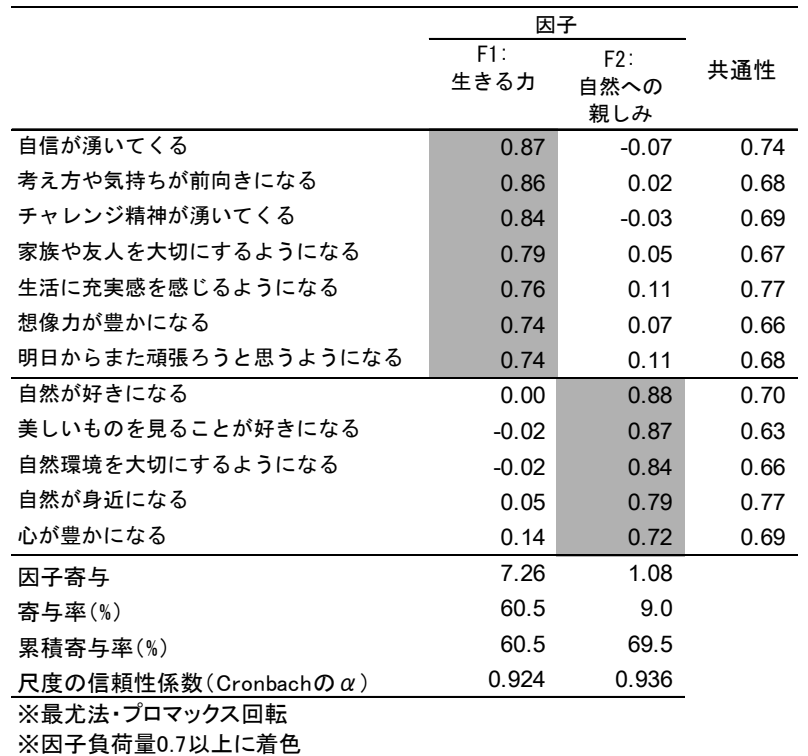




\section{3. 調査結果および考察}

（1）山岳系国立公園を利用して得られる効用の特徵

山岳系国立公園を訪れたことで得られた自身の変化，個別効用 の平均值を見ると，「自然環境を大切にするようになる」，「心が豊 かになる」，「自然が好きになる」といった変化が多く見られた (図 -2)。これらは北海道及び本州中部の山岳系の自然公園利用がも たらす効用の特徵と言える。

\section{（2）効用と活動との関係}

次に, 山岳系国立公園で行ったそれぞれの活動の有無によって, 得られる効用の大きさが異なるのかについて検証を行った。検証 にあたり，効用に関する項目が 12 項目に及ぶため，因子分析に よって 2 つの因子を抽出した（表一4）。それぞれの因子には, $\lceil\mathrm{F} 1$ : 生きる力」,「F2：自然への親しみ」と名付けた。

そして，活動の実施有無による効用の差を把握するため，2 因 子の因子得点平均值の差について $\mathrm{t}$ 検定を行った（表一5）。その 結果，遊覧船，温泉，宿泊を除く活動において，その実施有無に よって得点に有意差がみられた。これら活動の有無による因子得 点の差を用い，X軸を「生きる力」喚起力，Y軸を「自然への親 しみ」喚起力とし，円の大きさをその活動の実施率として，効用 喚起力と活動の実施状況との関係を図一 3 に示した。「生きる力」 と「自然への親しみ」双方を強く喚起する活動は，「植物観賞」「野 生動物観察」「芸術活動（写真撮影など）」「ハイキング」「ビジタ 一センター見学」であった。このうち，「芸術活動」や「ビジター センター見学」の実施率は低位にとどまった。また，身体的な負 荷の高い「登山」「キャンプ」は実施率が低く, 「生きる力」喚起 力は大きいが，「自然への親しみ」喚起力は小さい。一方で, 全て の活動のベースとなる「景色を見る」は 9 割以上の利用者が体験 している活動であり，「自然への親しみ」喚起力は大きいが，「生 きる力」喚起力は小さい傾向にあった。

（3）感動, 満足, 総合効用, ロイヤルティの関係性

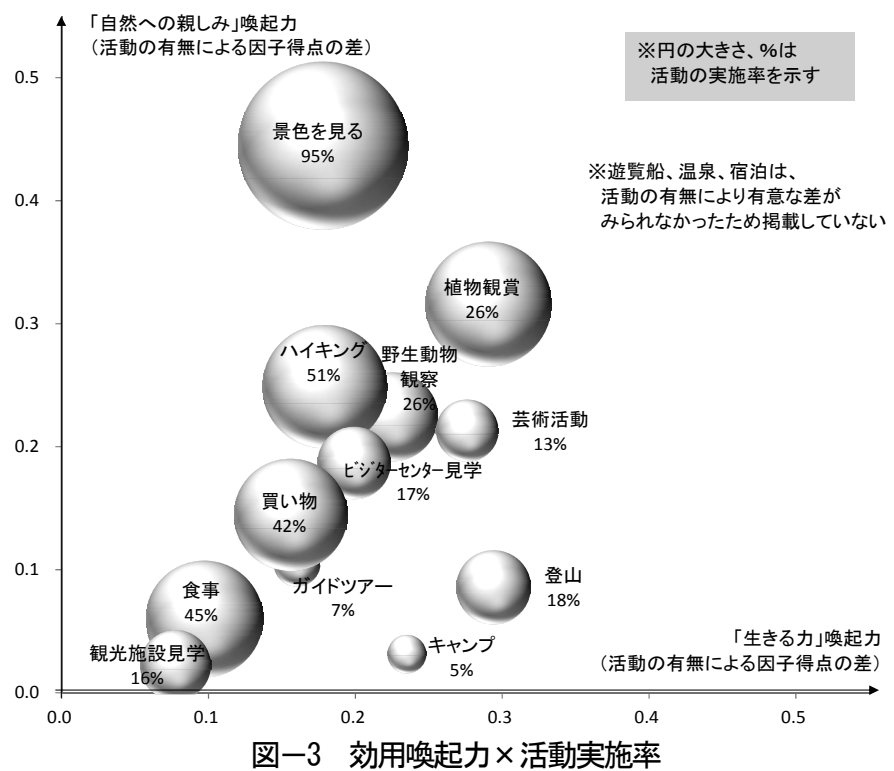

表一6 感動, 満足, 総合効用, ロイヤルティの平均値

\begin{tabular}{lcc}
\hline & 平均値 & 標準偏差 \\
\hline 感動 & 5.84 & 0.97 \\
満足 & 5.90 & 1.00 \\
総合効用 & 5.81 & 1.00 \\
ロイヤルティ(回答サンプルごとに(1) (4)を平均した值) & 5.93 & 1.01 \\
(1)紹介意向 & 6.10 & 1.12 \\
(2)当該地域への1年以内の再来訪意向 & 5.36 & 1.65 \\
(3)当該地域への別の季節の再来訪意向 & 6.15 & 1.18 \\
(4)自然観光地への1年以内の来訪意向 & 5.96 & 1.27 \\
\hline
\end{tabular}

続いて, 感動, 満足, 総合効用, ロイヤルティの関係性につい て分析を行った。なお，ここでのロイヤルティは，紹介意向，当 該地域への 1 年以内の再来訪意向，当該地域への別の季節の再来 訪意向, 自然観光地への来訪意向の 4 項目の平均值を観測变数と して用いた。感動，満足，総合効用については設問自体が観測変 数（7 段階評価）であったことから，ロイヤルティについても整 合性をとるために，観測変数として扱うこととした。なお，ロイ ヤルティの変数合成の妥当性を確認したところ, 尺度の信頼性を 表す Cronbach の a 係数は 0.76 となり, ロイヤルティとして一体 的に扱うことは適切であることが確認できた。なお，これらの平 均值及び標準偏差については，表一6に示した通りであった。

既往研究では，満足を向上することでロイヤルティも高まるこ とが示されている14)が，感動や効用が，満足・ロイヤルティの意 識構造においてどのような位置付けにあるのかは明らかとなって いない。そこで，満足・ロイヤルティモデル 14$) に ，$ 各用語の定義 6) 8) 11) 13)に従い時間軸にもとづいて感動と効用を加え，「感動は満 足に影響を与え，満足は人生を豊かにするような効用に影響を与 える。満足はロイヤルティにも影響を与える。」という図一 1 で整 理した概念図に基づいた基本モデルを構築し，パス解析によって 検証した。この仮説に基づき変数間のパスを設定したモデル (ベ 一スラインモデル）を作成して分析を行ったところ，適合度は， $\mathrm{X}^{2}=589.729, \mathrm{df}=2, \mathrm{CFI}=0.903, \mathrm{RMSEA}=0.232, \mathrm{AGFI}=$ $0.756, \mathrm{SRMR}=0.081, \mathrm{AIC}=56117.491$ であった。変数間に一切 の関係を仮定しない独立モデルとの比較によりモデルの適合度の 改善度合いを示し 0.9 以上が望ましいとされる CFI，モデルによ って説明できなかった残差を示し 0.1 未満が望ましいとされる SRMR については 18)当てはまりがよかったが，モデルの分布と 真の分布との 1 自由度あたりの乘離の程度を示すRMSEAの值が 0.1 以上であれば当てはまりが悪いとされていること，また，モ デルの説明力の目安を示寸 AGFI は 0.9 以上が目安とされている

\section{表一5 活動実施有無による因子得点の比較（ $\mathrm{t}$ 検定）}

\begin{tabular}{|c|c|c|c|c|c|c|}
\hline \multirow[b]{2}{*}{ 実施有無 } & \multicolumn{3}{|c|}{ F1:生きる力 } & \multicolumn{3}{|c|}{ F2:自然への親しみ } \\
\hline & あり & なし & 差 & あり & なし & 差 \\
\hline 景色を見る & 0.007 & -0.171 & $0.178^{*}$ & 0.019 & -0.426 & $0.445^{\star}$ \\
\hline 野生動物観察 & 0.161 & -0.064 & $0.225^{*}$ & 0.161 & -0.064 & $0.225^{\star}$ \\
\hline 植物観賞 & 0.137 & -0.153 & $0.291^{*}$ & 0.150 & -0.166 & $0.316^{*}$ \\
\hline ハイキング & 0.084 & -0.095 & $0.179^{*}$ & 0.117 & -0.132 & $0.249^{*}$ \\
\hline 登山 & 0.237 & -0.057 & $0.294^{*}$ & 0.069 & -0.017 & $0.086^{*}$ \\
\hline 遊覧船 & -0.015 & 0.001 & -0.015 & -0.008 & 0.001 & -0.009 \\
\hline ガイドッアー & 0.147 & -0.013 & $0.160^{*}$ & 0.097 & -0.008 & $0.105^{*}$ \\
\hline ビジターセンター見学 & 0.161 & -0.038 & $0.199^{*}$ & 0.151 & -0.035 & $0.186^{*}$ \\
\hline 参拝 & 0.000 & -0.001 & 0.001 & -0.081 & 0.022 & $-0.103^{*}$ \\
\hline 観光施設見学 & 0.064 & -0.014 & $0.078^{*}$ & 0.019 & -0.004 & 0.023 \\
\hline 芸術活動 & 0.238 & -0.037 & $0.276^{*}$ & 0.184 & -0.029 & $0.213^{*}$ \\
\hline 食事 & 0.051 & -0.047 & $0.097^{*}$ & 0.032 & -0.029 & $0.060^{*}$ \\
\hline 買い物 & 0.085 & -0.071 & $0.156^{*}$ & 0.079 & -0.066 & $0.145^{\star}$ \\
\hline 温泉 & 0.023 & -0.018 & 0.040 & -0.004 & 0.003 & -0.006 \\
\hline 宿泊 & 0.029 & -0.021 & 0.050 & 0.001 & -0.001 & 0.002 \\
\hline キャンプ & 0.221 & -0.014 & $0.235^{*}$ & 0.030 & -0.002 & 0.032 \\
\hline
\end{tabular}

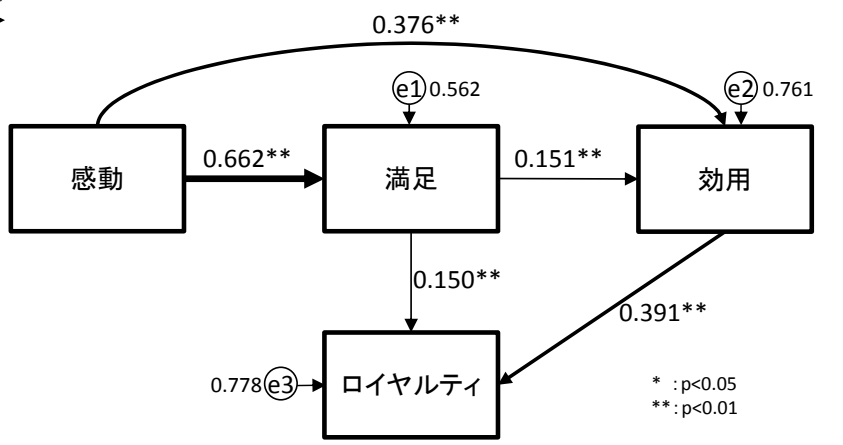

図－4＼cjkstart感動，満足，効用，ロイヤルティの構造モデル 
こと 18)から，このモデルは基準を満たしていなかった。このこと は, 図一 1 で整理した概念図に基づいた基本モデルにおける関係 性にとどまらず，感動から効用への直接関係や効用からロイヤル ティへの関係の可能性を示唆している。そこで，変数間のパスの 増減と適合度の変化を加味しながら, パスの有意性を吟味した ${ }^{15)}$ なお，修正に当たっては，修正が実質科学的であること，交差妥 当性があること（後述する対象とする公園や活動が違っても構造 が不変であること）に留意した。モデルの構造を決定する過程で は, 感動から効用への影響の有無, 感動及び効用からロイヤルテ イへの影響の有無を考慮し，複数モデルについて適合度指標の值 から比較検討した結果, 最終的に作成された修正モデル（図一-4) の適合度は，RMSEA が 0.1 以下になったことに加え，競合モデ ルの相対的な比較のために用いられ，值が小さいほどモデルとデ 一タとの乘離が小さくよいモデルとされている AIC の值 ${ }^{18)}$ が最 も小さく, 他の適合度指標に関してもべースラインモデルよりも 良好な值となった（ $\mathrm{X}^{2}=49.520, \mathrm{df}=1, \mathrm{CFI}=0.992, \mathrm{AGFI}=$ $0.955, \mathrm{SRMR}=0.019, \mathrm{RMSEA}=0.094, \mathrm{AIC}=55579.182)$ 。その ため, この「感動は満足に影響を与え，満足は人生を豊かにする ような効用に影響を与える。感動は, 効用にも直接影響を与える。 さらに，満足，効用はそれぞれロイヤルティにも影響を与える。」 といらモデルを決定した。

次に, 標準化パス係数をみると, 感動から満足のパス係数が 0.662 と高い值を示しており, 感動から効用, 効用からロイヤル ティのパス係数も，それぞれ $0.376,0.391$ と比較的高い值を示 した。一方, 満足から効用, 満足からロイヤルティへのパス係数 は低い值となった。なお，パス係数は全て $1 \%$ 水準で統計的に有 意であった。

これらの結果から，国立公園利用者の感動，満足，効用，ロイ ヤルティの関係性について，以下の点が明らかとなった。
・感動から満足へのパス係数は 0.662 と高い值を示寸一方，満足 から効用へのパス係数は 0.151 と低い值に留まったことから, 感動は満足に強く影響するが, 満足が効用に与える影響は弱い。 ・感動から効用へのパス係数が 0.376 に対し, 満足から効用への パス係数は 0.151 であることから，効用は満足よりも感動から 直接受ける影響のほうが強い。

・ロイヤルティ（再来訪意向・紹介意向）へのパス係数が，満足 からは 0.150, 効用からは 0.391 となることから, ロイヤルテ イは, 満足よりも, 効用から受ける影響が強い。「人生が豊かに なった」と感じることは，「また訪れたい」「誰かに紹介したい」 「自然豊かな地域を訪れたい」といった人を動か寸原動力に繋 がる。

次に，公園によって感動，満足，効用，ロイヤルティの関係性 が異なるのかを把握するため, 4 公園間の同時分析を行った（表 -7上)。同時分析の結果, 適合度指標は一定水準を満たしており $\left(\mathrm{x}^{2}=58.456, \mathrm{df}=4, \mathrm{CFI}=0.991, \mathrm{AGFI}=0.998, \mathrm{SRMR}=\right.$ 0.017， RMSEA=0.050, AIC = 55141.362），いずれの公園にお いても, 国立公園利用者全体の構造と変わらないことが分かった。 また，パス係数をみると，知床は感動が効用に与える影響が他公 園に比べて強いこと，立山は感動が満足に与える影響が他公園に 比べて強いこと, 日光及び上高地は満足が効用及びロイヤルティ に与える影響が他公園に比べて強いことが示された。

さらに, 活動による関倸性についての分析を試みた (表一7下)。 まず, 16 種類の活動に対する対応分析で得られた因子得点を利用 し, 公園利用者をクラスター分析で自然観察系, 観光系, 登山系 の 3 タイプに分類した (表一 8 , 図-5)。この 3 タイプ間の同時 分析を行ったところ（適合度指標は $\mathrm{X}^{2}=53.116, \mathrm{df}=3, \mathrm{CFI}=$ $0.992, \mathrm{AGFI}=0.998, \mathrm{SRMR}=0.016, \mathrm{RMSEA}=0.056, \mathrm{AIC}=$ 55125.911 となり, 一定水準を確保), 公園別同様, いずれの活動

表-7 公園別 - 活動別の感動, 満足, 効用, ロイヤルティのパス係数

\begin{tabular}{|c|c|c|c|c|c|}
\hline 公園別 & 知床 & 日光 & 上高地 & 立山 & 公園間の比較 \\
\hline 感動 $\rightarrow$ 効用 & $0.517 * *$ & $0.362 * *$ & $0.331 * *$ & $0.360 * *$ & 知床-他公園で有意差あり \\
\hline 感動 $\rightarrow$ 満足 & $0.646 * *$ & $0.637 * *$ & $0.685 * *$ & $0.696 * *$ & 知床-立山以外は有意差あり \\
\hline 満足 一効用 & $0.120 *$ & $0.173 * *$ & $0.214 * *$ & $0.106 * *$ & 知床-上高地、立山-日光、立山-上高地で有意差あり \\
\hline 満足ロロイヤルティ & 0.086 & $0.225 * *$ & $0.187 * *$ & 0.036 & 知床-日光、知床-上高地、立山-日光、立山-上高地で有意差あり \\
\hline 効用 $\rightarrow$ ロイルルィ & $0.442 * *$ & $0.391 * *$ & $0.400 * *$ & $0.350 * *$ & 知床-立山、上高地-立山で有意差あり \\
\hline & & & & & $*: p<0.05, * *: p<0.01$ \\
\hline 活動タイプ別 & 登山系 & 自然鑑賞系 & 観光系 & & 活動間の比較 \\
\hline 感動 $\rightarrow$ 効用 & $0.322 * *$ & $0.370 * *$ & $0.399 * *$ & & 登山系-観光系で有意差あり \\
\hline 感動 $\rightarrow$ 満足 & $0.705 * *$ & $0.667 * *$ & $0.651 * *$ & & 有意差なし \\
\hline 満足一効用 & $0.249 * *$ & $0.117 * *$ & $0.161 * *$ & & 有意差なし \\
\hline 満足十ロイヤルティ & 0.100 & $0.170 * *$ & $0.140 * *$ & & 有意差なし \\
\hline 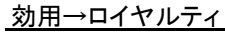 & $0.440 * *$ & $0.370 * *$ & $0.400 * *$ & & 有意差なし \\
\hline
\end{tabular}

\section{表一8 活動タイプ別回答者数及び活動実施率}

\begin{tabular}{|c|c|c|c|c|}
\hline 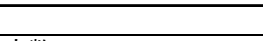 & 自然観察系 & 登山系 & 観光系 & 全体 \\
\hline \multirow{2}{*}{$\begin{array}{l}\text { 度数 } \\
\text { 構成比 }\end{array}$} & 2,656 & 395 & 2,766 & 5,817 \\
\hline & $45.7 \%$ & $6.8 \%$ & $47.6 \%$ & $100.0 \%$ \\
\hline \multirow{2}{*}{$\begin{array}{c}\text { 景色を見る } \\
\text { 植物の観賞 }\end{array}$} & $97.6 \%$ & $77.2 \%$ & $94.8 \%$ & $94.9 \%$ \\
\hline & $65.1 \%$ & $30.1 \%$ & $42.6 \%$ & $52.0 \%$ \\
\hline ハイキング & $71.9 \%$ & $15.2 \%$ & $35.9 \%$ & $50.9 \%$ \\
\hline 食事 & $29.9 \%$ & $5.8 \%$ & $65.1 \%$ & $45.0 \%$ \\
\hline 買い物 & $30.0 \%$ & $6.6 \%$ & $59.2 \%$ & $42.3 \%$ \\
\hline 温泉 & $21.6 \%$ & $20.8 \%$ & $62.9 \%$ & $41.2 \%$ \\
\hline 活 宿泊(宿泊施設) & $23.4 \%$ & $28.9 \%$ & $58.7 \%$ & $40.6 \%$ \\
\hline 動 野生動物観察 & $30.4 \%$ & $13.2 \%$ & $24.4 \%$ & $26.4 \%$ \\
\hline 実 参拝·社寺仏閣訪問 & $2.0 \%$ & $6.1 \%$ & $39.2 \%$ & $20.0 \%$ \\
\hline 施 登山 & $10.1 \%$ & $94.4 \%$ & $15.1 \%$ & $18.2 \%$ \\
\hline 率 ビジターセンター見学 & $17.5 \%$ & $8.1 \%$ & $18.6 \%$ & $17.4 \%$ \\
\hline 観光施設見学 & $1.2 \%$ & $0.5 \%$ & $32.8 \%$ & $16.2 \%$ \\
\hline 芸術活動 & $10.2 \%$ & $5.6 \%$ & $16.0 \%$ & $12.7 \%$ \\
\hline 遊覧船 & $0.9 \%$ & $1.8 \%$ & $17.1 \%$ & $8.6 \%$ \\
\hline ガイドツアーへの参加 & $1.8 \%$ & $0.8 \%$ & $13.0 \%$ & $7.0 \%$ \\
\hline 宿泊 (キャンプ) & $0.5 \%$ & $32.4 \%$ & $5.3 \%$ & $4.9 \%$ \\
\hline その他 & $1.5 \%$ & $1.0 \%$ & $3.9 \%$ & $2.6 \%$ \\
\hline
\end{tabular}

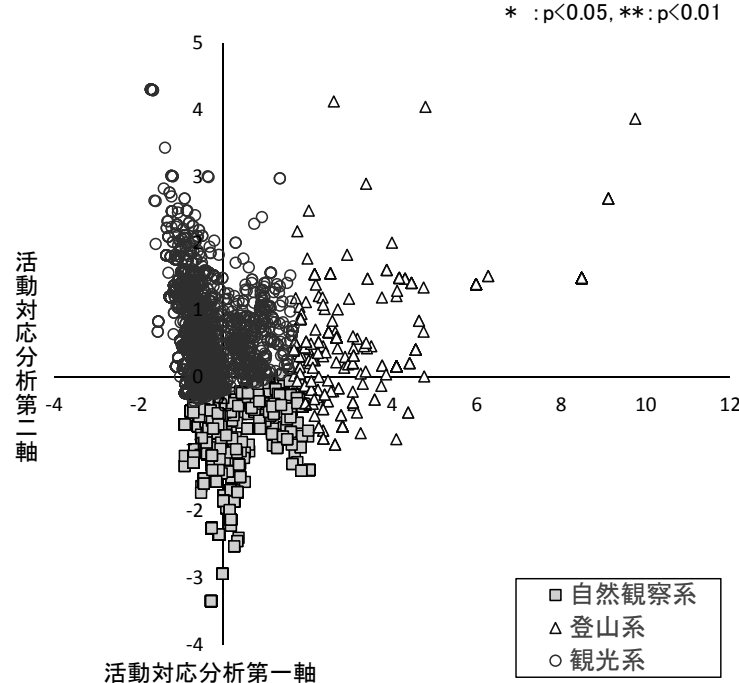

図－5＼cjkstart活動によるクラスター分析結果（回答者の散布図） 
タイプにおいても構造が同じであることが示された。また，パス 係数からは，自然観察系および観光系は，感動から効用への影響 が強いのに対し，登山体験については感動から効用への影響がや や弱く，満足から効用への影響がやや強いことがわかった。これ は, 登山系の活動については, 感動したかどうかよりも,「頂上を 目指したい」など自身の動機が達成されたことによる成果が満足 を高め，それが効用にも影響を与えているためと考えられる。

\section{4. まとめ}

本研究では，北海道及び本州中部の山岳系国立公園利用者に対 する意識調査を実施することにより，既存研究では明らかとなっ ていない, 山岳系国立公園を利用して得られる心理的効用の特徵, 効用と活動との関係性，感動・満足・効用・ロイヤルティの関係 性の分析を試みた。

1 つ目の論点である山岳系国立公園を利用して得られる心理的 効用の特徵については，設定した 12 項目の個別効用に対して公 園を訪れたことで得られた自身の変化の度合いを7段階評価で取 得した結果, 平均值が高い順から，「自然環境を大切にするように なる」，「心が豊かになる」，「自然が好きになる」となった。これ らは山岳系国立公園を利用して得られる効用の特徵であると言え る。さらに，「人生が豊かになる」と設定した総合効用についても その平均值が高いことから，山岳系国立公園利用は豊かな人生を 送ることに寄与する，ということが示された。さらに，12 項目の 効用を因子分析したところ, 山岳系国立公園利用の効用は, 「生き る力」と「自然への親しみ」の大きく 2 つ集約されることが分 かった。

2 つ目の論点である効用と活動の関係については，活動の実施 有無による効用の差を確認したところ, 山岳系国立公園でどのよ うな活動を行うかによってもたらされる効用が異なることが示さ れた。「植物観賞」「野生動物観察」「ハイキング」「ビジターセン ター見学」「芸術活動」は「生きる力」及び「自然への親しみ」双 方を喚起し，「登山」「キャンプ」は「生きる力」を，「景色を見る」 は「自然への親しみ」を喚起する。視覚で捉える美しさやそこで しか感じられない圧倒的な雄大さなどは利用者の自然への親しみ を強化する。人生が豊かになるとさらに実感するためには，そう いった直感だけではなく，その背景にある世界をあわせて体感す ることが大切であり，国立公園でゆったりとした時間を過ごして 写真撮影・描画などの芸術活動や動植物観察にふけること, ビジ ターセンター見学などを通して自然の背景や見方を学ぶことによ り，生きる力も含めたより強い効用がもたらされる。

3 点目の論点である感動・満足・効用・ロイヤルティの関係性 については, パス解析によって検証を行い，「感動は満足に影響を 与え, 満足は人生を豊かにするような効用に影響を与える。感動 は，効用にも直接影響を与える。さらに，満足，効用はそれぞれ ロイヤルティにも影響を与える。よいうモデル構造が確認された。 さらにパス係数からは, 感動が満足に与える影響に対して満足が 効用に与える影響は弱いこと，効用は満足よりも感動から直接受 ける影響のほうが強いこと， ロイヤルティは満足よりも効用から 受ける影響が強いことが示された。感動が高まると効用が高まり, 効用が高まるとロイヤルティが高まる。つまり, 感動を高めるこ とは自然公園利用の促進に寄与寸る。活動による関係性について は, 16 種類の活動に対する対応分析で得られた因子得点を利用し, 公園利用者をクラスター分析で分類した上でパス解析の同時分析 を行った結果，モデル構造は現地での活動内容によらず同じであ ることが確認された。活動タイプ別にみたパス係数からは，自然 観察系およひ観光系の活動は感動が高まると効用が高まりやすい ことが示された。登山系の活動についても感動は重要な要素では あるが，登頂など自身の目的を達成することによる満足から効用
への影響が強いと考えられる。

公園利用者の人生の豊かさへの貢献のためには, 公園管理にお いて, 感動をもたらす場面を設定することが重要である。また, 効用を喚起する自然の背景や見方を学ぶことや動植物観察などの 活動の実施率が低位にとどまっていることから，これらの活動の さらなる促進が期待される。

なお，本研究における効用は訪問直後に聞いたものであり，効 用が持続しているのか, 人生が豊かになったのかを把握するため には, 別の調査が必要である。また, 満足やロイヤルティについ ても意向を把握していることから，実際に家族や知人に紹介した のか, 再来訪したのか, といった観点での研究も必要である。

謝辞: 本研究を進めるにあたり, 様々なご助言をいただいた「自然 公園の利用者意識に関する研究会」委員並びに調査および回答に ご協力いただいた関係機関および利用者各位に深謝する.

\section{補注及び引用文献}

1）財団法人日本交通公社 (2004) : 観光読本(第 2 版) : 東洋経済新報社, $284 \mathrm{pp}$

2）小林昭裕（2004）：自然公園での利用体験の質を把握するための概念及び手法上の 問題点に関する一考察 : ランドスケープ研究 67(5), 591-596

3）愛甲哲也 (2003) : 山岳性自然公園における利用者の混䧱感評価と収容力に関寸る 研究: 北海道大学大学院農学研究科邦文紀要, 61-114

4) 山本清龍他 (2004) : 利用者の意識構造分析を通した富士登山の問題の構造化: ラ ンドスケープ研究 67(5), 689-692

5）伊藤太一 (2003) : 日米比較による森林レクリエーション研究の検証 : 日本林学会 誌 85(1), 33-46

6) Driver, B., Brown, P., and Peterson, G. (1991) : Research on leisure benefits : an introduction to this volume. In: Driver, B. and others, eds., Benefits of Leisure. State College, PA: Venture Publishing, 3-11

7) Manning, R. (2010) : Studies in Outdoor Recreation :Search and Research for Satisfaction. 3rd ed : Oregon State University Press, 468pp

8) 戸梶要紀彦 (2001) : 『感動』喚起のメカニズムについ : 認知科学 8(4), 360-368

9) 戸梶要紀彦 (2004) : 『感動』体験の効果についてー人が変化するメカニズムー： 広島大学マネジメント研究 4,27-37

10) 古谷勝則 (1998) :思い出に残る自然風景に関寸る研究:ランドスケープ研究 61(5), 669-674

11) Oliver, R.L. (1999): Whence Consumer Loyalty? : Journal of Marketing63 (Special Issue), 33-44

12）山田雄一五木田玲子 (2014) : 旅行動機がロイヤルティに及ぼす影響: 日本観光 研究学会機関誌 26(1), 1-6

13) Hunt, H. K. (1997） :"CS/D-Overview and Future Directions," Conceptualization and Measurement of Consumer Satisfaction and Dissatisfaction, H. Keith Hunt (Ed.) : Marketing Science Institute, 490pp

14）観光庁 (財団法人日本交通公社)（2010）: 観光地の鬼力向上に向けた評価手法調 查事業報告書 : $115 \mathrm{pp}$

15) Rebecca Weston, Paul A. Gore Jr. (2006): A Brief Guide to Structural Equation Modeling, The Counseling Psychologist, 34(1), 719-751

16）「自然公園の利用者意識に関寸る研究会」は, 愛甲哲也 (北海道大学大学院准教授), 阿部宗広 (財団法人自然公園財団事務局長), 上杉哲郎 (環境省自然環境局国立公園 課長), 熊谷嘉隆 (国際教養大学教授), 柴崎茂光 (国立歷史民俗博物館准教授), 土 屋俊幸 (東京農工大学大学院教授), 寺崎竜雄 (財団法人日本交通公社観光調査部長), 山本清龍 (岩手大学准教授) の 8 名の委員で構成（五十剖順，敬省略。所属は当時 のもの)。設置期間は 2011 年 4 月 2012 年 3 月。

17）観光庁 : 統計情報・白書 : 旅行・観光消費動向調査ホームページ

<http://www.mlit.go.jp/kankocho/siryou/toukei/shouhidoukou.html>,2014.8.15 更 新, 2014.9.13 参照

18) 朝野熙彦·鈴木督久.小島隆矢 (2005) : 入門共分散構造分析の実際: 講談社, 166pp 